\title{
Empowering Women through E-Business: A Study on Women Entrepreneurs in Dhaka City
}

\section{Tanjela Hossain}

Senior Lecturer (HRM), Department of Business Administration, Central Women's University, Dhaka, BANGLADESH

*E-mail for correspondence: tanjelahossain@gmail.com

https://doi.org/10.18034/abr.v8i3.167

\begin{abstract}
This paper tries to evaluate the effectiveness of e-business on the empowerment of women. A survey has been administered to identify the effects of Women Entrepreneurship through e-business on Women Empowerment related attitudes. I have collected data through a semi-structured questionnaire from a sample of 100 women entrepreneurs operating online businesses located in Dhaka city. 15 employees' personally interviewed and other 85 respondents were surveyed through e-mail and social network sites. The findings of the study indicate various factors about women empowerment. Results reveal that indicators of women empowerment are mainly (1) Economic Freedom, (2) Greater social independency and acceptability, and (3) Sense of self-worth. Twenty questions are developed to evaluate the effectiveness of e-business on the empowerment of women for mentioned three indicators. The findings of this study reveal that e-business is a powerful tool in enhancing women empowerment. Women believe that e-business is one of the easiest ways to become entrepreneur which is in turn empowering them in different social issues.
\end{abstract}

Key words: Empowerment, Entrepreneurship, Self-worth, e-business, Bangladesh

\section{INTRODUCTION}

Online or e-business now has become a buzzword in Bangladesh. Online shopping enables the customers to order a product or service through the Internet. Google Trends shows that "online shopping" is the fourth mostsearched phrase in Bangladesh. Aside from famous online shops, there are a few hundred little-known online shops and web pages in Dhaka and other big cities. It is noticeable that most of the owner of the online business are women. The entrepreneurship of women is regarded to be an effective way for the economic development and empowerment of women. Online or e-business makes it easier for women to be an entrepreneur. It is noticeable that women are particularly interested in e-business because it is hassle-free and does not require large capital or physical stores (Geetha and Barani, 2012). Online business has become a media of women empowerment in our country that is recommendable.

Women empowerment is a new addition in the area of gender literature. In a general sense, it refers to empowering women to be self-dependent by providing them access to all the freedoms and opportunities, which they were denied in the past only because of their being women. More specifically we can say, women empowerment is nothing but enhancing, enriching, emphasizing their position in the power structure, their decision-making freedom in different social issues as well as in their family related issues. Empowerment of women has five components: women sense of self-worth; their right to have and to determine choices; their right to have access to opportunities and resource; their right to have the power to control their own lives, both within and outside the home; and their ability to influence the direction of social change to create a more just social and economic order, nationally and internationally (Singla and Syal, 1998). In today's competitive world, there are various ways by which women get themselves empowered. The entrepreneurship of women is considered to be an effective instrument for the economic development and empowerment of women (Bisht and Sharma, 1991).

\section{ObJectives OF the Study}

In a broad sense, the purpose of this study is to find out how e-business have influenced women's life in Bangladesh. It also aims to study how the women have 
become empowered by e-business. The specific objectives are given below:

- To investigate various factors influencing women Empowerment in Bangladesh.

- To explore the influence of e-business on the empowerment of women.

- To have an idea about how women perceive ebusiness as a medium of self-empowerment.

- To explore the relationship between Women empowerment and E-business

\section{REVIEW OF LITERATURE}

To explore women's empowerment through E-business, it is necessary to understand the fundamentals of the concept of empowerment. The notion of women`s empowerment first came up in the 1970s introduced by third world feminists and women's organizations to depict the process of achieving women's equality by transforming social and political structures at national and international levels (Bisnath and Elson, 2000). The spread of these discourses has introduced the concept to a broad range of development areas, such as education, health care, rural development, and worker' rights.

The empowerment concept has various meanings in different contexts. A reason for this might be that empowerment involves intangible and non-material things, like self-actualization, capacity-building and social integration, which change depending on the sociocultural and political context (Midgley, 2003).

Empowerment is not exclusively a concept related to women but is commonly used in this context. Speer and Hughey define empowerment as "the expansion of assets and capabilities of poor people to participate in, negotiate with, influence, control, and hold accountable institutions that affect their lives" (Speer and Hughey, 1995: 730). Zimmerman states that the term empowerment includes "self-strength, control, self-power, self-reliance, own choice, life of dignity in accordance with one's values, capability of fighting for one's rights, independence, own decision making, being free, awakening and capability" (Zimmerman, 1990: 169).

A comprehensive study by Malhorta and Schuler employing Kabeer`s definition of empowerment comprises a range of indicators used to measure women`s empowerment. They state that women`s empowerment needs to occur in six different areas: economic, sociocultural, familial/interpersonal, legal, political, and psychological. Each of these can be measured at differing levels from the household, to the community, to broader national, regional, and global levels. For example, in the economic dimension, indicators of empowerment can include women's control over household income; their access to employment, credit, and markets; their representation in high-paying jobs; and representation of their interests in macroeconomic policies (Malhotra and Schuler, 2005).

Women entrepreneurship through online business have emerged especially in the urban areas of Bangladesh. Though few studies were conducted on this regard, but no significant research study was done on the influence of online business on women empowerment in Bangladesh.

Mellita and Cholil (2012) described the aspects and role of e-business for gender empowerment in developing country. Empowering women through online business requires training, gender analysis, planning, designing, implementation and monitoring assessment and paying attention effect on women live and their conditions.

Singh (2008) indicates the underlying factors behind the initiating of women entrepreneurship in India. Also, the challenges to entering into a business venture were also identified. The study mentioned that obstacles which lie within the path of women entrepreneurship is mainly associated with social un-acceptance as female entrepreneurs, lack of interaction with other successful entrepreneurs, gender discrimination, less priority given to women entrepreneurs by bankers to provide business loans, missing network as well as family responsibility.

Jan and Shar (2008) have explored the various economic opportunities for women, developing their entrepreneurial skills, empowering them through the cooperative sector of the economy along with presenting ways to improve their socio-economic status.

Minniti (2009), detailed in her monographic reviews relative to women entrepreneurship across different disciplines (sociology, economics, psychology, anthropology, etc) and the various issues related to the division of labor.

Women Entrepreneurs are increasingly using e-commerce to start-up their own online business. Various studies have identified a set of critical factors which underlie successful women entrepreneurs. In particular, government and institutional support, the involvement of societal environment, training and management, increased access to the market, and best managerial practices are stressed. Thus, Minnitti et al. (2005) argue that men continue to exhibit a more active participation in entrepreneurship, as compared to women. The data suggested that the shortfalls occurs more likely with the middle-income nations where women are $25 \%$ of entrepreneurs. In contrast, women entrepreneurs are more active comparatively in the high-income countries, with over $33 \%$ of the total, and in the remaining low-income countries with a $41 \%$ participation rate (Minnitti et al., 2005). Mitchell (2004) found the ways and targets of men and women are influenced by the stereotype behavior. The stereotype indicators such as targets, negative perspective and self-appropriate behavior are dangerous to their selffulfillment cycle. Thus, many women entrepreneurs are motivated by the safety level measures for their families. 
Entrepreneurship combines caring for their families as well as bringing the money for them for their survival and fulfillment of their aspirations. This is visible in several Asian countries including Indonesia and Singapore (Mitchell, 2004; Sebora et al., 2009).

Meenakshi (2015) argues that the government is playing a vital role in influencing women to become entrepreneurs. The government's support is encouraging women to become an entrepreneur by developing entrepreneurial intention among them. In support of these views, Mat and Razak (2011) suggest that governmental policies are vital for encouraging women to become entrepreneurs. In their view, several factors affect the entrepreneurial activities of women, including education, attitude and experience level of the individual.

In case of Bangladesh, although some e-commerce businesses create a prominent sign of success, the sector is still lack behind to be developed, structured, and its influence to economic development is expected to increase rapidly, after the continuing phase of customer adaptation and ease with e-business, a reasonable market perception is attained. In recent years, several established business houses have opened up online pages while others are starting a new as exclusively online business for its relatively less capital-intensive nature. These trends are not limited only to Dhaka, but semi-urban, and rural areas as well. The Governments of Bangladesh takes initiative to provide a solid Internet backbone, inspiring a wellgrounded telecommunication sector, connecting all government offices, and opening up IT Parks are all leading indicators that point to the e-commerce sector's growth potential (Ahmed and Adib, 2016).

However, women's empowerment and a country's level of economic development are inextricably linked (Boserup, 1970; Elson, 1995; Marchand and Parpart, 1995; Nussbaum, 2001; Sen, 2000.

With the numerous limitations to urban life in Dhaka city, people are becoming more interested in online shopping, with an increasing supply of virtual businesses to match. Convenience, competitive pricing, range of products, dedicated service, improving payment security and flexibility and demand from buyers and sellers are the most inspiring factors and with the help of them ecommerce has witnessed a mushrooming of the online shopping websites.

In modern days e-commerce is developing as powerful tool for gender empowerment. It will bring new information resources and can open new communication channels for women entrepreneurs of marginalized community. Empowering women through e-commerce need high-level training, gender analysis, planning, designing, implementation and monitoring assessment and paying attention to the effect on women live and their conditions. Government plays significant role in creating a favorable policy environment because they take central role in the progress and use of e commerce among women entrepreneur and become a leading-edge user of $\mathrm{e}$ commerce and its application for empowering women (Goswami and Dutta, 2017).

Sarup and Sons Publishers (Jan and Shar, 2008) in "Entrepreneurship and Women Empowerment", have represented the various economic opportunities for women, developing their entrepreneurial skills, empowering them through the cooperative sector of the economy along with presenting ways to improve their socio-economic status. In different research paper authors represent potential opportunities associated with development of women entrepreneurship which provides economic upliftment. E-commerce is the sector where women can utilize their capabilities with total freedom.

\section{Methodology}

The research has made extensive use of both primary and secondary data. I have collected all the primary data by administering a questionnaire to respondents in the selected companies. Interviews have also been conducted to access the information about the E-Business and its effects on Women Empowerment.

\section{Research design}

The research is descriptive analytical and empirical.

Study Place: Dhaka City, Bangladesh

Study Period: June 2018 - August 2018

\section{Study of Target Population}

Women Entrepreneurs involved in E-business and living in Dhaka and near Dhaka City were selected purposively as the target population of the study. It is to be noted that about 100 women entrepreneurs through online or e-business who are in operation and living in Dhaka and near Dhaka city are targeted for the study. The universe of the study comprises of Women entrepreneurs living in Bangladesh.

\section{Sampling Technique}

I have selected the sample entrepreneurs through convenience sampling and judgment or purposive sampling method. Some were taken where it was possible to gain access to the information and entrepreneurs who were interested in helping with the study. The Convenient sampling method was used to select the sample from the population.

\section{Data Collection Technique and List of variables for} preparing a Questionnaire

Respondents were asked to give opinions on the fivepoint scale extending from strongly significant to not at all significant, strongly satisfied to strongly dissatisfied, strongly agree to strongly disagree. A semi-structured questionnaire was used to collect data. I just give my questionnaire to 100 women entrepreneurs. Though some findings are extracted from my observations. 


\section{List of Key Variables for preparing a Questionnaire}

To understand the relation between online business and women empowerment a questionnaire has been prepared based on the various parameters regarding women empowerment.

\section{Data Processing and Analysis technique}

By analyzing the relation between e-business and women empowerment of the surveyed women, I tried to conclude by using my own analytical and cognitive abilities. Microsoft Excel and SPSS 22 software have been used to process survey data. Hypothesis testing through t-test, Simple average method or percentage method has been used to calculate quantitative data converted from qualitative data collected through a semi-structured questionnaire.

\section{ANALYSIS AND FINDINGS}

Respondents were asked a series of open questions, semiopen questions, multiple choice questions, dichotomous questions. Findings and Analysis are presented below based on the questions of the questionnaire used in this study:

The Demographic profile of the respondents: At the very beginning of my data collection, I have classified the respondents by their age, monthly family income, qualification, experience and marital status for their responses regarding the quality of work life.

Table 1: Demographic factors of the respondents

\begin{tabular}{|c|c|c|}
\hline Demographic factors & No. of Respondents & Percentage (\%) \\
\hline \multicolumn{3}{|c|}{ Age } \\
\hline a) Below 30 years & 41 & $41 \%$ \\
\hline b) $30-40$ years & 34 & $34 \%$ \\
\hline c) $40-50$ years & 18 & $18 \%$ \\
\hline d) 50 above & 7 & $7 \%$ \\
\hline \multicolumn{3}{|c|}{ Educational Qualification } \\
\hline a) School Level & 13 & $13 \%$ \\
\hline b) Diploma & 18 & $18 \%$ \\
\hline c) Graduate & 46 & $46 \%$ \\
\hline $\begin{array}{l}\text { d) Post Graduate and } \\
\text { above }\end{array}$ & 23 & $23 \%$ \\
\hline \multicolumn{3}{|c|}{ Experience in Online Business } \\
\hline a) Less than 1 years & 17 & $17 \%$ \\
\hline b) 1 years -3 years & 47 & $47 \%$ \\
\hline c) 3 years -5 years & 24 & $24 \%$ \\
\hline d) 5 years- 7 years & 9 & $9 \%$ \\
\hline e) 7 years+ & 3 & $3 \%$ \\
\hline \multicolumn{3}{|c|}{ Marital Status } \\
\hline a) Unmarried & 31 & $31 \%$ \\
\hline b) Married & 43 & $43 \%$ \\
\hline c) Divorced & 21 & $21 \%$ \\
\hline d) Single Parent & 5 & $5 \%$ \\
\hline \multicolumn{3}{|c|}{ Household Expense in BDT } \\
\hline a) Less than 30000 & 13 & $13 \%$ \\
\hline b) $30000-50000$ & 37 & $37 \%$ \\
\hline c) $50000-70000$ & 34 & $34 \%$ \\
\hline
\end{tabular}

\begin{tabular}{|l|c|c|}
\hline d) $70000-90000$ & 14 & $14 \%$ \\
\hline e) $90000+$ & 2 & $2 \%$ \\
\hline
\end{tabular}

Contribution of women in Household Income (in BDT)

\begin{tabular}{|l|c|c|}
\hline a) Less than 10000 & 9 & $9 \%$ \\
\hline b) $10000-20000$ & 43 & $43 \%$ \\
\hline c) $20000-30000$ & 24 & $24 \%$ \\
\hline d) $30000-400000$ & 21 & $21 \%$ \\
\hline e) $40000+$ & 3 & $3 \%$ \\
\hline
\end{tabular}

\begin{tabular}{|c|r|r|}
\hline e) $40000+$ & 3 & $3 \%$ \\
\hline \multicolumn{2}{|c|}{ Monthly Income from online Business (in BDT) }
\end{tabular}

\begin{tabular}{|l|c|c|}
\hline a) Less than 15000 & 11 & $11 \%$ \\
\hline b) $15000-25000$ & 34 & $34 \%$ \\
\hline c) $25000-35000$ & 31 & $31 \%$ \\
\hline d) $35000-45000$ & 18 & $18 \%$ \\
\hline e) $45000+$ & 6 & $6 \%$ \\
\hline
\end{tabular}

Table 1 highlights that the age range of majority (41\%) of women entrepreneur is below 30 years age group out of 100 respondents, $34 \%$ were in $30-40$ years age group, $18 \%$ belonged to $40-50$ years age group and only $7 \%$ respondents were in age group of 50 years above. The table also indicates that a majority of women entrepreneur (46\%) have graduation, $18 \%$ have Diploma. $23 \%$ are post graduates and above educational degrees and only $13 \%$ have school level education. It is also clear from the table that $17 \%$ of the respondents have experiences less than one year, $47 \%$ have experience between $1-3$ years, $24 \%$ of the respondents have 3-5 years of experience, $9 \%$ of the respondents have 5-7 years of experience, $3 \%$ of the respondents hold more than 7 years of experience. In this study, most of the employees $(43 \%)$ are married, $31 \%$ are unmarried, $21 \%$ are divorced, and $5 \%$ are single parents.

Most $(37 \%)$ of the respondents have the monthly expenditure of BDT $30000-50000,34 \%$ belonged to $50000-$ 70000 , only $2 \%$ have more than 90000 BDT expenditure.

However, the level of contribution of women entrepreneur in household expenditure is noticeable. $43 \%$ of my total respondents marked that they are contributing an amount between 10 to 20 thousand per month. $24 \%$ and $21 \%$ said the level of contribution lies on 20000-30000 and 30000-40000 BDT. Which is remarkable undoubtedly.

Only $6 \%$ of the respondents have a monthly income from ebusiness of above Tk.45,000, $18 \%$ are in the income category of Tk.35,000-45,000, 31\% are in the income category of Tk.25,000$35,000,34 \%$ are in the income category of Tk.15,000-25,000 and $11 \%$ are in the income category of below Tk.15,000.

\section{Perceptions of respondents toward various factors influencing women Empowerment:}

Women Employee's level of Priority regarding different measures to be taken by the organization for improving Quality of Work life:

Here I tried to rank the Priority of women entrepreneurs regarding many indicators of women empowerment through the weighted average method. 
Table 2: Priority ranks given by the women entrepreneurs regarding the Women Empowerment

\begin{tabular}{|l|l|c|c|c|c|c|c|c|c|}
\hline No & Factors & SDA (1) & DA (2) & N (3) & A (4) & SA (5) & $\begin{array}{c}\text { Weighted } \\
\text { Score }\end{array}$ & $\begin{array}{c}\text { Weighted } \\
\text { Average }\end{array}$ & Rank \\
\hline i. & Economic Freedom & 1 & 3 & 11 & 43 & 42 & 422 & 28.133 & 2 \\
\hline ii. & Social Recognition & 0 & 6 & 18 & 47 & 29 & 399 & 26.6 & 4 \\
\hline iii. & Self-independency & 0 & 0 & 15 & 46 & 39 & 424 & 28.267 & 1 \\
\hline iv. & Participation in family Decision making & 0 & 5 & 19 & 53 & 23 & 394 & 26.27 & 5 \\
\hline v. & Control over family resources & 2 & 12 & 17 & 47 & 22 & 375 & 25 & 7 \\
\hline vi. & Control over Expenditure & 3 & 9 & 7 & 61 & 20 & 386 & 25.733 & 6 \\
\hline vii. & Control over own live related issues & 0 & 0 & 3 & 73 & 24 & 421 & 28.067 & 3 \\
\hline
\end{tabular}

(SDA=Strongly Disagree, DA=Disagree, $N=$ Neutral, $A=$ Agree, $S A=$ Strongly Agree)

Table 2 shows the priority given by the women entrepreneurs to reflect their priority for Women Empowerment. The ranking shows that Selfindependency has given the most priority to have empowerment. Economic Freedom and Control over own live related issues are also addressed as a priority. Interestingly table reveals the least priority to Control over family resources as an indicator of Women Empowerment.

Table 3: Perception of the respondents towards Women Empowerment through E-business

\begin{tabular}{|c|c|c|c|c|}
\hline No. & Particulars & Mean & $\begin{array}{c}\text { Standard } \\
\text { Deviation }\end{array}$ & Variance \\
\hline \multicolumn{5}{|c|}{ Raise in Social Status } \\
\hline 1 & $\begin{array}{l}\text { E-business enables the } \\
\text { women to develop } \\
\text { leadership in the society. }\end{array}$ & 4.04 & 0.79 & 0.625 \\
\hline 2 & $\begin{array}{l}\text { Entrepreneurship } \\
\text { through E-business } \\
\text { enables women to get a } \\
\text { sense of gender equality. }\end{array}$ & 3.84 & 1.051 & 1.105 \\
\hline 3 & $\begin{array}{l}\text { Women } \\
\text { entrepreneurship in E- } \\
\text { business creates a } \\
\text { distinctiver social } \\
\text { entity/image for women. }\end{array}$ & 4.11 & 0.815 & 0.665 \\
\hline 4 & $\begin{array}{l}\text { Entrepreneurship } \\
\text { through E-business is a } \\
\text { source of inspiration for } \\
\text { other women. }\end{array}$ & 4.2 & 0.752 & 0.566 \\
\hline 5 & $\begin{array}{l}\text { Women entrepreneurship } \\
\text { through } \text { E-business } \\
\text { creates a greater social } \\
\text { acceptability for women. }\end{array}$ & 3.91 & 1.016 & 1.032 \\
\hline \multicolumn{5}{|c|}{ Raise in Economic Status } \\
\hline 6 & $\begin{array}{l}\text { E-business enables } \\
\text { women to achieve the } \\
\text { economic freedom. }\end{array}$ & 3.88 & 0.891 & 0.794 \\
\hline 7 & $\begin{array}{l}\text { Women involvement in } \\
\text { E-business enhances the } \\
\text { standard of living. }\end{array}$ & 4.08 & 0.419 & 0.175 \\
\hline 8 & $\begin{array}{l}\text { Entrepreneurship } \\
\text { through E-business } \\
\text { enables women to } \\
\text { contribute in family } \\
\text { income. }\end{array}$ & 3.9 & 0.644 & 0.414 \\
\hline
\end{tabular}

\begin{tabular}{|c|c|c|c|c|}
\hline 9 & $\begin{array}{ll} & \text { Women } \\
\text { entrepreneurship } \\
\text { through } \quad \text { E-business } \\
\text { enhances r women } \\
\text { employability }\end{array}$ & 3.86 & 0.964 & 0.93 \\
\hline 10 & $\begin{array}{l}\text { E-business enables } \\
\text { women to a control over } \\
\text { Expenditure }\end{array}$ & 3.49 & 1.267 & 1.606 \\
\hline \multicolumn{5}{|c|}{ Raise in Self-worth } \\
\hline 11 & \begin{tabular}{|lr} 
Entrepreneurship \\
through & E-business \\
increases & self- \\
independency &
\end{tabular} & 3.62 & 0.982 & 0.965 \\
\hline 12 & $\begin{array}{l}\text { E-business is a catalyst for } \\
\text { women to be in business. }\end{array}$ & 4.24 & 0.806 & 0.649 \\
\hline 13 & $\begin{array}{l}\text { E-business boosts the } \\
\text { feelings of ownership and } \\
\text { leadership. }\end{array}$ & 4.39 & 0.65 & 0.422 \\
\hline 14 & $\begin{array}{l}\text { Entrepreneurship } \\
\text { through } \quad \text { E-business } \\
\text { increases women's self- } \\
\text { confidence. }\end{array}$ & 4 & 0.739 & 0.545 \\
\hline 15 & $\begin{array}{lr}\text { Women in } & \text { E-business } \\
\text { increases } & \text { the } \\
\text { participation } & \text { in } \\
\text { household } & \text { decision } \\
\text { making. } & \end{array}$ & 3.31 & 1.331 & 1.772 \\
\hline 16 & $\begin{array}{l}\text { Women entrepreneurship } \\
\text { through E-business } \\
\text { eradicates the fear of risk } \\
\text { taking/enhance the risk- } \\
\text { taking tendency. }\end{array}$ & 3.59 & 1.256 & 1.578 \\
\hline
\end{tabular}

The measure of central tendency was calculated to interpret the variability of the scores for Hierarchical structure. Table 3 provided the average responses on analysis of Perception of the respondents towards Women Empowerment through E-business.

The highest mean score was 4.2 on the first five questions as women entrepreneurs agreed with these statements, apart from the question no 5 and 8 relating to the development of entrepreneurship and social acceptability of women where the mean was 3.84 and 3.91 respectively indicating that most women entrepreneurs have agreed that Entrepreneurship through E-business raise their social Status. 
Analogous to raise in the social Status coding, a scale average of three or above on Raise in economic status indicated a Neutral view with the five questions (9-13. On these set of questions, the 100 respondents had an average mean score of $4.08(S D=0.419)$ indicating that the women agreed with the statements, suggesting that they are predicting their standard of living has increased due to the involvement in E-business (Table 3).

The mean value in Table 3 also provided the average responses on Raise in Self-worth of the women entrepreneurs who are involved in E-business (Q.14-Q.19). The highest mean score was 4 and above which indicates that women have agreed the statements asked on enhancement of self-worth through E-entrepreneurship.

In most cases the highest mean score was 3 and above which suggested the employees were not sure about these statements regarding self-independency, participation on decision making and risk-taking tendency.

\section{Analysis of Relationship between Women empowerment and E-business:}

Here I try to find out the relationship between Analysis of Relationship between Women empowerment and Ebusiness by using simple percentage analysis

Table 4: Relation between women Empowerment and Ebusiness

\begin{tabular}{|l|c|c|c|c|c|}
\hline Particulars & $\begin{array}{c}\text { Strongly } \\
\text { Disagree } \\
(1)\end{array}$ & $\begin{array}{c}\text { Disagree } \\
(2)\end{array}$ & $\begin{array}{c}\text { Neutral } \\
(3)\end{array}$ & $\begin{array}{c}\text { Agree } \\
(4)\end{array}$ & $\begin{array}{c}\text { Strongly } \\
\text { Agree } \\
(5)\end{array}$ \\
\hline Frequency & 4 & 16 & 15 & 52 & 13 \\
\hline Percentage & $4 \%$ & $16 \%$ & $15 \%$ & $52 \%$ & $13 \%$ \\
\hline
\end{tabular}

The table 4 shows the relation between women entrepreneurship and E-business. Respondents were asked that whether e-business makes it easier to become an entrepreneur or not! Table shows clearly that most of the women entrepreneurs (52\%) have agreed that ebusiness make it easier to be involved in entrepreneurship.

\section{Conclusion}

Women's empowerment incases of social status, economic security, self-actualization, etc. is an inevitable part of country's overall development. Without women the mainstream development program, sustainable development process is just nearly impossible. Not only that, this development would always be a dream without active and meaningful participation of the country's women in it. After completing the analysis and finding part the study found that e-business is the most convenient and easiest option to run business for the women entrepreneurs in Bangladesh.

Women Entrepreneurship through e-business has enhanced their economic status and decision-making power. Economic status, self-worth, self-confidence, control over own life-related issues, control over resources, and social status of women entrepreneurs are the variables that define empowerment of women. If women gain economic freedom, social recognition, they gain both visibility and a voice at home, workplace and community. This has an impact on their social status regarding increase in their leadership ability, gender equality and so on. According to the study, women are becoming more interested in establishing their own online business in Bangladesh as it is easier than any other form of business. So, governance and policy formation should support the women entrepreneurs so that they can develop and empower themselves. It will lead to the development of our country's sustainable economic growth, creates employment opportunities as well as make a contribution towards the women entrepreneurs' family and community.

\section{REFERENCES}

Ahmed S. I. and Adib S. (2016)- E-Commerce in BangladeshCenter for Enterprise and Society

Bisht, N. S. and Sharma, P. K. (1991), Entrepreneurship Expectation and Experience, 2nd Ed. Bombay: Himalaya Publishing House, vol. 2, pp 23-24.

Bisnath, S., and Elson, D. (2000). Women's empowerment revisited. Background Paper for Progress of the World's Women

Boserup, E. (1970). Women's role in economic development. London: Allen and Unwin.

Elson, D. (Ed.). (1995). Male bias in the development process. Manchester: Manchester University Press.

Geetha S. N and Barani G. (2012) Empowering Women through Entrepreneurship: A study in Tamil Nadu, India International Journal of Trade, Economics and Finance, Vol. 3, No. 2

Goswami, A., \& Dutta, S. (2017). E-Commerce Adoption by Women Entrepreneurs in India: An Application of the UTAUT Model. Business and Economic Research, 6(2), 440454. doi:http:/ / dx.doi.org/10.5296/ber.v6i2.10560

Jan, M. and Shar, N (2008), "Entrepreneurship and Women Empowerment", Sarup and Sons Publishers.

Malhotra, A., and Schuler, S. R. (2005). Women's empowerment as a variable in international development. Measuring Empowerment: Cross-Disciplinary Perspectives, ,71-88.

Marchand, M., and Parpart, J.L. (Eds.). (1995). Feminism/ Postmodernism/Development. London and New York: Routledge.

Mat, I. E. N. and Razak, R. C. 2011. Attributes, Environment Factors and Women Entrepreneurial Activity: A Literature Review. Asian Social Science 7(9), pp. 124-130.

Meenakshi. 2015. Factors Influencing the Women in EEntrepreneurship. International Journal of Business Management and Scientific Research 12, pp. 53-63.

Mellita, D., and Cholil, W. (2012). E Commerce and Women Empowerment: Challenge for Women-Owned Small Business in Developing Country. International Conference on Business Management and IS (Vol. 1, No. 1). 
Midgley, J. (2003). Social development: The intellectual heritage. Journal of International Development, 15(7), 831-844.

Minniti, M. (2009) Gender Issues in Entrepreneurship, Now Publishers, 01-Dec-2009.

Minnitti, M., Arenius, P., and Langowitz, N. (2005). Report on women and entrepreneurship. Global entrepreneurship monitor. The Center for Women's Leadership at Babson College, Wellesley, MA.

Mitchell, B. C. (2004). Motives of entrepreneurs: A case study of South Africa. Journal of Entrepreneurship, 13(2), 167-183

Nussbaum, M. (2001). Women and human development. Cambridge: Cambridge University Press.

Sebora, T. C., Lee, S. M., and Sukasame, N. (2009). Critical success factors for e-commerce entrepreneurship: an empirical study of Thailand. Small Business Economics, 32(3), 303-316.

Sen, A. (2000). Development as freedom. New York: Anchor Books.
Singh, S. P. (2008), An Insight Into The Emergence Of Womenowned Businesses As an Economic Force in India, presented at Special Conference of the Strategic Management Society, December 12-14, 2008, Indian School of Business, Hyderabad

Singla, B. K. and Syal P. (1998), "Group entrepreneurship for women, entrepreneurship and small business," in Proc. of the 4th Ed., Jaipur Rawat Publications, vol. 3, pp 47-48,.

Speer, P. W., and Hughey, J. (1995). Community organizing: An ecological route to empowerment and power. American Journal of Community Psychology, 23(5), 729-748.

www.dhakatribune.com/business/commerce/e-commerceboost-economic-growth

Zimmerman, M. A. (1990). Taking aim on empowerment research: On the distinction between individual and psychological conceptions. American Journal of Community Psychology, 18(1), 169-177. 
Online Archive: https://abc.us.org/ojs/index.php/abr/issue/archive 